\title{
Value for Money Moderates External Pressure, Environmental Uncertainty on Budget Goals Clarity
}

\author{
Tumpal Manik* \\ Accounting Departement, Faculty of Economics, Universitas Maritim Raja Ali Haji \\ Jl. Politeknik Senggarang - Tanjungpinang, Kepulauan Riau, Indonesia \\ e-mail:*tmanyk@gmail.com \\ * Corresponding Author
}

\begin{abstract}
The research purpose is to analyze effect of external pressures, environmental uncertainty, budget quality, locus of control and value for money on budget goals clarity, then to test value for money and locus of control to moderate the relationship between external pressure, environmental uncertainty, quality budget against clarity on budget goals clarity. The research was conducted in Kepulauan Riau Province, used 85 data questionnaires getting from despondences. the first Data processing used classical assumption test, validity and reliability test, and then testing hypothesis test of used t-test and f-test. Empirically, the first to investigate the statistical results of research hypothesis shown that external pressure is a significant positive effect on budget goals clarity; second, environmental uncertainty is a positive significant effect on budget goals clarity; fourth, the budget quality is a significant positive effect budget goals clarity; third, value for money is a positive significant effect on budget goals clarity; fourth, Then the results of the moderation test show that the value for many can weaken the relationship between external pressure and environmental uncertainty on budget goals clarity, but value for many can be to improve relationship between budget quality on budget goals clarity. The final Empirical test to shown that locus of control is not moderating variable between external pressure, environmental uncertainty on budget goals clarity.
\end{abstract}

Keywords: Budget Goals Clarity, Environmental Uncertainty, External Pressure, Value for money

Article History: Received: September , 12020 Revised: September, 72020 Accepted: October, 122020

How to cite: Manik, T. (2020). Value for Money Moderates External Pressure, Environmental Uncertainty on Budget Goals Clarity. Akrual: Jurnal Akuntansi, 12(1):34-48. DOI: https://doi.org/10.26740/jaj.v12n1.p34-48

\section{INTRODUCTION}

The budget goals clarity of local government is often spotlight at the public because budget goals clarity is considered to have no impact on improving the economy of the community, the availability of budget as the basis for implementing local governments to advance their regions, it is demanded to improve accountability, the performance of government agencies that will encourage clarity of budget targets, which can improve public trust in the government. If the quality of local government budgets is low then the quality of government functions tends to be weak then the clarity of local government budget targets is also considered not on target, even not reaching the priorities scale of the regional government, this is usually due to environmental uncertainty, external pressure and quality of budgets regional government. This study wants to test and analyze; First simultaneously and partially; the influence of external pressures, environmental uncertainty, budget quality, locus of control on budget goals clarity. Second; Proving the influence of locus of 
control and value for money moderate the relationship between external pressure, environmental uncertainty, budget quality on budget goals clarity.

The previous research regarding the impact of environmental uncertainty on budget goals clarity of local government targets at individuals involved in budgeting. According Gede (2014), Anugerah et al. (2015), the research of environmental uncertainty has a positive effect on the accountability of local government performance. While the results research of Agung (2018), shown that environmental uncertainty has a positive effect on budgetary slack, not in line with Huseno (2017), uncertainty of environmental has no significant effect on budgetary slack, and budget quality has a significant effect on the effectiveness of government organizations. Saputro (2016), external pressure has a significant negative effect on budget accuracy, Yunaz (2016), Nasrul (2017) and Dwi. et al (2018), consistent results that external pressure has a significant positive effect on the application of financial reporting transparency, Suluh (2014) and Andriyani (2016), found that, only the clarity of budget objectives as a budget quality criterion has a significant positive effect on budget execution performance particularly the application of financial transparency.

External pressure related to intervention from outside the SKP/OPD, in the form of encouragement or refusal for the implementation of a policy, such as support or resistance from the community government prohibitions in the form of regulations legal order and norms that apply in society can affect structure and operational activities of government organizations. The characteristics of external pressure an organization consists of four others: technological changes, political and legal pressures, socio-cultural demographic pressures and economic changes (Mangkuprawira, 2014), Saputro (2016), external pressure has a significant negative effect on the variable budget accuracy in the Regional Government of Cilacap Regency. Other research conducted by Ridha (2012), Amelia (2015), Purnamasari (2015), Masruroh (2015), Hamdi (2017), Noprizal (2017) and Suryandari (2019), shows that external pressure has an effect on the implementation of financial report transparency and Setyowati (2017), pressure from external parties is usually in the form of government regulations, non-governmental organizations (NGOs), Audit Board of the Republic of Indonesia (BPK), and other formal and non-formal institutions. Based on the description, the first hypothesis raised was:

\section{H1: There is significant positive relationship between external pressure and budget goals clarity}

Environmental uncertainty causes the emergence of new problems from the actions that will be taken by the organization's leadership in running managing organization, facing a high risk of failure because program planning that has been prepared beforehand will change and affect the value of the budget. Problems that will be faced during conditions of environmental uncertainty if the leader of the organization does not have sufficient information regarding the state of the environment so that it will cause difficulties in predicting environmental will occur to changes. Previous research by Setyowati (2017), said that environmental uncertainty includes changes in government regulations, changes in community dynamics, and changes in the organization. Research 
by Masruroh (2015), Hamdi (2017), Yunaz (2017) and Suryandari (2019), shows that environmental uncertainty has an influence on the implementation of financial reporting transparency.

Budget characteristics (budget planning, budget control, budget sophistication, budget participation, clarity of budget targets, budget evaluation and difficulty of budget targets have a significant positive effect on financial performance (Silva, 2012). Meanwhile according Adisasmita (2011), the limited capacity of regional funding requires regional governments to manage regional expenditure efficiently and effectively. Therefore, regional spending must be managed carefully in line with the principles of budget management. Suluh (2014), he found that only budget clarity as a criterion for budget quality had a significant positive effect on the performance of the KPPN budget implementation in Malang. Based on the description, the second hypothesis raised was:

H2 : There is significant positive relationship between environmental uncertainty and budget goals clarity

\section{H3 : There is significant positive relationship between budged quality and budget goals clarity}

Value for money moderate the relationship between external pressure, environmental uncertainty and budget quality on budget goals clarity refer to Andrianto (2007), value for money is an important concept in public sector organizations, value for money means respect for money. This means that every rupiah must be valued properly and used as well as possible. According by Mardiasmo (2009), value for money is the management of public sector organizations based on three main elements, namely: economic, efficient and effective. Indicators value for money is 1) economical in managing administrative procedures. Karacan (2015), the concept of value for money is found in the implementation of a performance-based budget based on three main indicators namely economy, efficiency and economic.

Fernandes (2015) and Pertiwi (2015), concluded that accountability has a positive and significant effect on budget management based on value for money. Adiwirya (2015), concluded that transparency has a positive effect on value for money-based budget performance. Meanwhile the results of research according to Premananda (2017), show that budget participation has a positive effect on value for money-based budget performance. According Wandari (2015), it is stated that there is an influence of monitoring variables on government budget performance variables on the basis of value for money and is supported by Hanafiah (2016), result of research that internal supervision has an effect on regional financial management. Based on the description, the hypothesis raised was:

H4 :There is significant positive relationship between value for money and budget goals clarity

H7a: Value for money able to weaken relationship between external pressures and budget goals clarity

H7b : Value for money able to weaken the relationship environmental uncertainty and budget goals clarity 
$H 7 c:$ Value for money able to weaken the relationship budged quality and budget goals clarity

Locos of control moderate the relationship between external pressure, environmental uncertainty and budget quality on budget goals clarity refers to Triana (2012), locus of control has no effect on budget slack. Nopriyanti (2016), states that locus of control has no effect on budget gaps and according to Hidayat (2016), locus of control has no effect on managerial performance and Pello (2014), locus of control, has a negative effect on the relationship between participatory budgeting and budgetary slack, this means that the implementation of locus of control is able to weaken the influence of the relationship between participatory budgeting and budgetary slack so that each individual has an internal locus of control.

The regional government budget as a major aspect is very important in planning, implementing the wheels of government and effective short-term control which have an impact on advancing the territory and the public benefit that the budget formulation process cannot be separated from the existence of internal control. Externally performance can run as intended. Control is carried out reflected in the behavior of the management control system that budget absorption is appropriate and right on target in implementing internal locus of control and external locus of control we need to understand what events of positive or negative. If it is positive, we would be nice implementation an internal locus of control. Meanwhile, if it is negative, we would be better if to implementation an external locus of control. Based on the description, the hypothesis raised was:

H5 :There is significant positive relationship between Locus of control and budget goals clarity

H8a :Locus of control able to weaken the relationship between external pressures with budget goals clarity

H8b :Locus of control able to weaken the relationship environmental uncertainty and budget goals clarity

H8c : Locus of control able to weaken the relationship budged quality and budget goals clarity

\section{RESEARCH METHOD}

Population, Sample and Data

The populations of this study used 23 Local Government Unit of Work (SKPD) in Kepulauan Riau Province, which had a budget of $\geq 20$ billion, for the positions; head of division, sub-head of division and staff finance administration at the fields of Finance, accounting, financial planning, and cash income/outcome finance treasurer fields. Data were obtained from the distribution of questionnaires to 120 respondents, but the questionnaires were received and back only 85 respondents, for 4 months from March July 2020 and there are 35 respondents did not fill out the questionnaire, because during the COVID-19 epidemic condition, the local government was implementing to work from home (WFH) system 
Operational and Variable Measurement

This research uses seven variables, independent variable External Pressure (X1), Environmental Uncertainty (X2), Budget Quality (X3), and two moderating variables, namely Value for Money (X4) Locus of Control (X5). Dependent variable is Budget Goals Clarity (Y). All of variables use primary data from questionnaires with a liker scale, rating range from $1-5(1=$ strongly disagree; $2=$ disagree; $3=$ neutral; $4=$ disagree; $5=$ strongly agree). Each variable has 8 questions, a total of 48 questions in the questionnaire. Testing data through validity and reliability tests, classical assumption tests, hypothesis testing using the t-statistic test, f-statistical test and coefficient of determination (R2).

\section{Research Model}

The research model uses multiple linear regression analysis as follows:

Model I; Regression model before moderation, the first model:

$\mathrm{BGC}=\beta 0+\beta 1 \mathrm{EP}+\beta 2 \mathrm{EU}+\beta 3 \mathrm{BQ}+\beta 4 \mathrm{VFM}+\beta 5 \mathrm{LoC}+\varepsilon$

Model II; Used interaction locus of control variable as the second moderating model $\mathrm{BGC}=\beta 0+\beta 6 \mathrm{EP}+\beta 7 \mathrm{EU}+\beta 8 \mathrm{BQ}+\beta 9 \mathrm{VFM}+\beta 10 \operatorname{Mod} 1+\beta 11 \operatorname{Mod} 2+$ $\beta 12 \operatorname{Mod} 3+\varepsilon$

Model III; Used interaction with value for money variable as the third moderating model $\mathrm{BGC}=\beta 0+\beta 13 \mathrm{EP}+\beta 14 \mathrm{EU}+\beta 15 \mathrm{BQ}+\beta 16 \mathrm{LoC}+\beta 17 \operatorname{Mod} 4+\beta 18 \mathrm{Mod} 5$

$$
+\beta 19 \operatorname{Mod} 6+\varepsilon
$$

Whereas: $\mathrm{BGC}=$ Budget Goal Clarity; EP $=$ External Pressure; EU = Environmental Uncertainty; $\mathrm{QB}=$ Quality Budget; VFM = Value for Money; LoC = Locos of Control; Mod = Moderation; Mod 1 = Interaction EP*VFM; Mod 2 = Interaction EU*VFM; Mod 3; = Interaction QB*VFM; Mod 4 = Interaction EP*LoC; Mod 5 = Interaction EU*LoC; Mod $6=$ Interaction QB*LoC

\section{RESULTS AND DISCUSSION}

Respondent's Description

Respondent's description on gender; Male 42 respondents (49.4\%), female 43 respondents (50.6\%). Respondents on Education; Diploma 3 is $12.9 \%$, Diploma 4 is $2.4 \%$, Bachelor (S1) is $74.1 \%$, Magister (S2) is $9.4 \%$ and Doctoral (S3) is $1.2 \%$. Meanwhile based on the age range; Age $20-25$ was $3.5 \%$, ages $26-30$ were $5.9 \%$, ages $31-35$ were $30.6 \%$, ages 40 50 were $20 \%$.

The highest descriptive statistical value is on budget goal clarity, with an average of 25.412 with a standard deviation of 4.902 . the second there are three variables value is 28 , namely the external pressure variable with an average of 21.188 standard deviation of 3.242; The budget quality variable has an average standard deviation of 22.518, 3.397 standard deviation and the value for money variable is 20.271 and a standard deviation is 4.863. The lowest value of 13 is the locus of control variable with an average of 16.6235 standard deviation of 2.5212 and a value for money with an average of 16.624 and a standard deviation of 2.512 


\section{Test Results of Validity, Reliability and Classical Assumptions}

The research data were normally distributed and declared free from multicollinearity because they meet the criteria for a Tolerance value $>0.10$. There are no symptoms of multicollinearity between independent variables. Heteroscedasticity testing with the scatter plot method shows a value> 0.05 , meaning that the data does not occur hetero, while the Durbin Watson value is 2.7259 , the comparison uses a significance value of $5 \%$, the number of samples is $85(\mathrm{n})$, and the number of independent variables is $5(\mathrm{k}=5)$, then in the Durbin Watson table, the du value is 1.73 . Because the DW value of 2.642 is greater than the upper limit (du) of 1.73 and less than $4-1.73$ (2.27), it can be concluded that there is no autocorrelation.

\section{The Result of Multiple Regression Before Moderation Variable}

Testing the hypothesis by using multiple linear regression tests before to test moderation. The test results of hypothesis can be seen in table.1, namely as follows.

Table 1. The Effects of External Pressure, Environmental Uncertainty, Budget Quality, Value for Money and Locus of Control on Budget Goal Clarity

\begin{tabular}{|c|c|c|c|c|}
\hline Variable Research & $\begin{array}{c}\text { Unstandardized } \\
\text { Coefficients }\end{array}$ & $\begin{array}{l}\text { Standardized } \\
\text { Coefficients }\end{array}$ & T-Test & $\begin{array}{l}\text { Probability } \\
\text { (Sig. } \alpha 0,05)\end{array}$ \\
\hline (Constant) & 3,720 & & 22,686 & 0,000 \\
\hline $\mathrm{EP} \quad(\mathrm{X} 1)$ & 0,189 & 0,271 & 3,740 & 0,000 \\
\hline EU (X2) & 0,372 & 0,430 & 7,375 & 0,000 \\
\hline QB (X3) & 0,982 & 1,217 & 16,902 & 0,000 \\
\hline VFM (X4) & 0,861 & 0,849 & 14,779 & 0,000 \\
\hline LoC (X5) & 0,686 & 0,694 & 11,356 & 0,000 \\
\hline$R$ Square & 0,918 & $F-T e s t$ & & 176,843 \\
\hline Adjusted R Square & 0,913 & Probability & & 0,000 \\
\hline \multicolumn{5}{|l|}{ Dependent Variable. } \\
\hline \multicolumn{5}{|c|}{ Source: Output questionnaire data processing with SPSS V.24, (2020) } \\
\hline \multicolumn{5}{|c|}{ Based on table 1, a regression equation model can be made, as follows: } \\
\hline \multicolumn{5}{|c|}{$\mathrm{BCG}=3,720+\beta_{1} 0.189+\beta_{2} 0.372+\beta_{3} 0.982+\beta_{4} 0.861+\beta_{5} 0.686+\varepsilon$} \\
\hline
\end{tabular}

\section{The Effect of External Pressure on Budget Goals Clarity}

The test results of external pressure variable have a coefficients value 0.189 , and a significance level $0.00<0.05$, as evidenced by the value of t-test $>$ t-table $(3.740>$ 1.9905), $\mathrm{H} 0$ is rejected and $\mathrm{H} 1$ is accepted, meaning the result that external pressure has a significant positive effect on budget goals clarity and theirs effects 18.9\%. External pressure can affect the budget goals clarity of government. If external pressure increases the budget goals clarity will become increasingly unclear and there will be increased pressure from outside parties to monitor clarity of budget targets. Including increasing external pressure on budget targets from vertical and horizontal sides will further increase the attention of local governments in managing budgets, so the principles of performancebased budgeting will fulfill the principles of economics, effectiveness and efficiency to motivate public sector organizations to give a good image.

The results external pressure variable to support the research of Nasrul (2017), Ridha (2012), Amelia (2015), Purnamasari (2015), Masruroh (2015), Yunaz (2016), Hamdi (2017), Noprizal (2017), Suryandari (2019) and Setyowati. (2017), that external pressure has a significant positive effect on budget goals clarity, including the implementation of 
financial reporting transparency. However contrary to the research results of Saputro, et al. (2016), that external pressure had a significant negative effect on the variable budget targeting accuracy. Conclusion, the higher the frequency of external pressure and will be less the achievement of budget accuracy.

\section{The Effect of Environmental Uncertainty on Budget Goals Clarity}

Environmental uncertainty has an estimated coefficient value with the parameter 0.372 and significance level $0.000<0.05$. Evidenced by the value of t-test $>$ t-table $(7,375>1,9901)$. $\mathrm{H} 0$ is rejected and $\mathrm{H} 2$ is accepted, meaning the result that environmental uncertainty has a significant positive effect on budget goals clarity. The more increasing, the uncertainty of the environment, the clarity of budget targets will be less and less on target. Environmental uncertainty a trigger for accurate budget realization is not in accordance with predetermined activity plans it will minimize the achievement of budget goals clarity. Environmental uncertainty causes the emergence of new problems from the actions that will be taken by the local government in running and managing the wheels of government and will face a high risk of failure in the accuracy of budget targets.

The results of this research to support the research of Masruroh (2015), Hamdi (2017), Yunaz (2017) and Suryandari (2019), showing that environmental uncertainty has an influence on budget goals clarity by application from financial reporting transparency. Environmental uncertainty includes changes in government regulations, changes in community dynamics, and changes in government organizations. The higher the environmental uncertainty in the form of the high frequency of changing regulations, the rapid turnover of employees and the number of regulations that are not related to one another the clarity of budget targets will be the less targeted.

\section{The Effect of Budget quality on Budget Goals Clarity}

Budget quality has an estimated coefficient value with the parameter 0.982 with a significance level $0.000<0.05$. Evidenced by the value t-test $>$ t-table $(16,902>1,9905)$. $\mathrm{HO}$ is rejected and $\mathrm{H} 3$ is accepted, meaning this result, that the budget quality has a significant positive effect on budget goals clarity and the effect is $98.2 \%$. The higher the quality of the budget, it will improve the performance of local governments, the clarity of budget goals clarity has an impact on improving the services of government organizations to the community, which are able to accelerate regional development of the Riau Islands Province. The factors that support the quality of regional budgets and expenditures are the quality of the Regional Government Budget Teams, the establishment of good synergy between the executive and legislative branches, the role of the Transparency and Participation Commission, and the efforts of local governments to make efficient use of budget goals clarity.

\section{The Effect of Value for Money on Budget Goals Clarity}

Value for money variable has an estimated coefficient value with the parameter 0,861with a significance level $0,000<0.05$. Evidenced the value t-test $>$ t-table $(14,779>1,9905)$, $\mathrm{H} 0$ is rejected and $\mathrm{H} 4$ is accepted, meaning result that value for money variable has a significant positive effect on budget goals clarity and the effect $68.6 \%$. The increasing 
exposure of the value for money model, the more clarity of budget targets will be. Value for money as a tool for public managers for SKPD/OPD to achieving public sector performance and their achieve programs. When using the principle of value for money, budget allocations and targets become efficiency, effectiveness, transparency, so that the results of local government programs are able to improve government performance, allocate resources, make decisions, and create public accountability. Value for money is one of the strategies for the government to control the budget so that the target of budget goals clarity is right on target.

The results of value for money variable indicate that accountability for budget management through the implementation of value for money according to Mardiasmo (2009), the opinion that management of public sector organizations is based on three main elements, namely economical, efficient and effective. The value for money model can minimize budget misuse. The results of this study to support Saskia. et al (2020), state that value for money has an effect on the management of public sector financial accounting, especially in budget management to be right target on budget goals clarity.

\section{The Effect of Locos of Control on Budget Goals Clarity}

Locos of control variable has an estimated coefficient value with the parameter 0,686 with a significance level of $0.000<0.05$. Evidenced the value t-test $>$ t-table $(11,356>1,9905)$, $\mathrm{H} 0$ is rejected and $\mathrm{H} 5$ is accepted, meaning the result that locos of control have a significant positive effect on budget goals clarity and the effect $86.1 \%$. If the application of the principle of external and internal locus of control is getting better, then the confidence of the leadership of the regional government organization has the ability to control the intelligibility of budget goals clarity targets.

Every individual leader of a government organization in SKPD/OPD with a good internal locus of control will have a high sense of responsibility because whatever the results of their work, good or bad they will be responsible for their performance that in this case, each individual is not going to do budgetary slack. The results of testing the locus of control variable do not support Triana (2012) of study, locus of control has no effect on budget slack and Nopriyanti (2016), states that locus of control has no effect on budget gaps, and according to Hidayat (2016), locus of control has no effect on managerial performance

The simultaneous test results show a significance value of 0.000 , namely $0.000<$ 0.05 . Then it is proven by the value of $\mathrm{f}$-test $>\mathrm{f}$-table $(176.843>2.3287)$, then $\mathrm{H}_{\mathbf{0}}$ rejected and $\mathrm{H}_{\mathbf{6}}$ accepted, it's concluded that the hypothesis (H6); It is proven that simultaneous variables (external pressure, environmental uncertainty, budget quality, locos of control, value for money) have a significant effect on budget goal clarity.

\section{Test Results Model II (Value for Money as a Moderation)}

This test to know value for money variable is able to strengthen or weaken the relationship between external pressure, environmental uncertainty on budget goal clarity. Testing is done by integrating the independent variables with the value for money, can be seen in Table.2, namely as follows: 
Table 2. The Effect of External Pressure, Environmental Uncertainty, Quality of Budget on Budget Goal Clarity and Value for Money as a Moderated Variable

\begin{tabular}{lcccc}
\hline $\begin{array}{l}\text { Variable } \\
\text { Research }\end{array}$ & $\begin{array}{c}\text { Unstandardized } \\
\text { Coefficients }\end{array}$ & $\begin{array}{c}\text { Standardized } \\
\text { Coefficients }\end{array}$ & T-Test & $\begin{array}{c}\text { Probability } \\
\text { (Sig. } \alpha \text { 0,05) }\end{array}$ \\
\hline (Constant) & 43,208 & & 5.989 & 0,000 \\
EP (X1) & $-3,429$ & $-2,268$ & $-6,196$ & 0,000 \\
EU (X2) & 5,527 & 4,896 & 15,656 & 0,000 \\
QB (X3) & $-2,671$ & $-1,851$ & $-8,491$ & 0,000 \\
VFM (X4) & $-1,713$ & $-1,700$ & $-4,774$ & 0,000 \\
EP*VFM & $-0,226$ & $-5,659$ & $-9,513$ & 0,000 \\
EU*VFM & $-0,274$ & $-6,449$ & $-14,368$ & 0,000 \\
QB*VFM & 0,113 & 3,512 & 7,595 & 0,000 \\
\hline
\end{tabular}

Dependent Variable: BGC (Budget Goal Clarity)

Source: Output questionnaire data processing with SPSS V.24, (2020)

Multiple regression model-2, to testing value for money as a moderating variable is able to weaken the relationship between external pressure, environmental uncertainty and budget quality on budget goal clarity, as follows:

$\mathrm{BGC}=43.208-\beta_{6} 3,429+\beta_{7} 5,527-\beta_{\mathbf{8}} 2,671-\beta_{9} 1,713-\beta_{10} 0.226-\beta_{11} 0.274$ $+\beta_{12} 0.113+\varepsilon$

The Effect of External Pressure on Budget Goal Clarity and Value for Money as a Moderated Variable

The interaction of external pressure with value for money (EP*VFM) has a t-test statistic 0.226 with a significance of 0.000 , smaller than less than $\alpha(0.05)$. This test shows that $\mathrm{H}_{0}$ is rejected and $\mathrm{H7a}$ is accepted, so it can be concluded that the interaction (EP*VFM) has a significant negative effect on budget goal clarity variable moderated by the value for money variable.

These results to indicate that the accountability of budget management through the implementation value for money, namely: economical (saving carefully) in the procurement and resources allocation, efficiency (efficient) in clarity of budget targets in the sense that the implementation value for money can minimize external pressure, and be effective (successful). use) in the sense of achieving clarity of budget goal clarity. This indicates that the implementation of value for money is able to reduce external pressure so that budget targets in accordance with the work program of the Riau Islands Province regional government get quality results in the budgeting process economically, efficiently and effectively.

The Effect of Environmental Uncertainty on Budget Goal Clarity and Value for Money as a Moderated Variable

The results of interaction of environmental uncertainty testing with value for money (EU*VFM), has a t-test statistic test of -14.368 with a significance of 0.000 smaller than less than $\alpha(0.05)$. This test shows that $\mathrm{H}_{0}$ is rejected and $\mathrm{H} 7_{\mathrm{b}}$ is accepted so that it can be concluded that interaction (EU*VFM) has a significant negative effect on the clarity variable, so value for money as a moderating variable is able to weaken the relationship of environmental uncertainty with budget goal clarity. 
The concept of value for money is able to control environmental uncertainty in order to achieve budget goal clarity targets well and maximally. Environmental uncertainty is one of the factors that often causes organizations to adapt to organizational conditions with the environment. In times of high environmental uncertainty, it is difficult for employees compiling budgets to predict the future due to the absence of accurate information, making it difficult for subordinates to create budgetary slack.

\section{The Effect of Budget Quality on Budget Goal Clarity and Value for Money as a Moderated Variable}

The test results of the interaction between budget quality and value for money (QB*VFM) have a statistical t-test of 7.595 with a significance of 0.000 , smaller than $\alpha(0.05)$. Evidenced by the value of $t$ test $>t$ table $(7.595>1.9905)$. This test shows that $\mathrm{H} 0$ is rejected and $\mathrm{H} 7 \mathrm{c}$ is accepted, so it can be concluded that interaction (QB*VFM) has a significant positive effect on the clarity variable, so value for money as a moderating variable can strengthen the relationship between budget quality and budget goal clarity. If the local government has a quality budget, then the local government has proven its performance to the public and has the competence to control the realization of budget goal clarity.

The importance of a quality SKPD/OPD budget, both of budget planning, clarity of budget targets, and budget evaluation is a supporting factor in improving regional financial performance economically, efficiently and effectively. Budget quality is related to the financial performance of local governments. Therefore, to improve regional financial performance, it can be done by increasing the quality of the budget, as evidence that the local government is able to control in the event of irregularities and fraud in regional financial management, so that it will increase efficient financial performance with the aim of achieving budget goal clarity.

Test Results Model III (Locus of Control as a Moderation)

This test to know locos of control variable is able to strengthen or weaken the relationship between external pressure, environmental uncertainty on budget goal clarity. Testing is done by integrating the independent variables with the locos of control. The test results are evidenced in the table below. 
Table 3. The Influence of External Pressure, Environmental Uncertainty, Budget

Quality on Budget Goal Clarity and Locos of Control as a Moderating Variable

\begin{tabular}{|c|c|c|c|c|}
\hline $\begin{array}{l}\text { Variable } \\
\text { Research }\end{array}$ & $\begin{array}{c}\text { Unstandardized } \\
\text { Coefficients }\end{array}$ & $\begin{array}{c}\text { Standardized } \\
\text { Coefficients }\end{array}$ & T-Test & $\begin{array}{l}\text { Probability } \\
\text { (Sig. } \alpha 0,05)\end{array}$ \\
\hline (Constant) & $-137,385$ & & $-3,750$ & 0,000 \\
\hline EP (X1) & 0,955 & 0,632 & 0,759 & 0,450 \\
\hline $\mathrm{UE}(\mathrm{X} 2)$ & 0,551 & 0,488 & 0,464 & 0,644 \\
\hline $\mathrm{QB}(\mathrm{X} 3)$ & 5,432 & 3,764 & 5,422 & 0,000 \\
\hline LoC (Z1) & 8,177 & 4,206 & 3,804 & 0,000 \\
\hline EP * LoC & $-0,038$ & $-0,774$ & $-0,543$ & 0,589 \\
\hline UE*LoC & 0,003 & 0,062 & 0,043 & 0,965 \\
\hline $\mathrm{QB} * \mathrm{LoC}$ & 0,304 & 4,814 & 5,192 & 0,000 \\
\hline
\end{tabular}

Dependent Variable: BGC (Budget Goal Clarity)

Source: Output questionnaire data processing with SPSS V.24, (2020)

Multiple regression model-3, to testing locus of control in terms of strengthening or weakening the relationship between external pressures, environmental uncertainty and budget quality on budget goal clarity. Based on table 3, a regression equation model 3 can be made, as follows:

$\mathrm{BGC}=-137,385+\beta_{13} 0,955+\beta_{14} 0,551+\beta_{15} 5,432+\beta_{16} 8,177+\beta_{17} 0.038+\beta_{18} 0.003+$ $\beta_{19} 0.304+\varepsilon$

The Effect of External Pressure on Budget Goal Clarity and Locus of Control as a Moderated Variable

The effect of external pressure on budget goal clarity is moderated by locus of control has an estimated coefficient value with the parameter -0.038 with a significance level of 0.589 $>0.05$, as evidenced by the value of t-test < t-table $(-0.543<1.9905), \mathrm{H} 0$ is accepted and $\mathrm{H} 8 \mathrm{a}$ is rejected. The meaning of external pressure does not have a significant effect budget goal clarity, so value for money is not a moderating variable. Value for money is not able to weaken the relationship between external pressure and clarity of budget targets.

The effect of Environmental Uncertainty on budget goal clarity and Locus of Control as a Moderated Variable

The effect of environmental uncertainty on budget goal clarity is moderated by locus of control, has an estimated coefficient value with parameter -0.003 with a significance level of $0.965>0.05$, as evidenced by the value of t-test $<\mathrm{t}$-table $(0.043<1.9905)$, H0 is accepted and H8b rejected. The meaning of environmental uncertainty does not have a significant effect on budget goal clarity, so the locus of control is not a modifying variable. Locus of control is' not able to weaken the relationship between environmental uncertainty on budget goal clarity. 
Wati, Tjaraka, \&Sudaryati, Do Managerial Ability Impact...

\section{The effect of Budget quality on budget goal clarity and Locus of Control as a Moderated Variable}

The effect of Budget quality on budget goal clarity moderated by locus of control, has an estimated coefficient value with parameters 0.304 with a significance level of $0.000<0.05$, as evidenced by the value of t-test $>\mathrm{t}$-table $(5.192>1.9905), \mathrm{H} 0$ is rejected and $\mathrm{H} 8 \mathrm{c}$ is accepted, meaning that the quality of the budget has a significant effect on the clarity of budget targets, then locus of control as a moderating variable is able to strengthen the relationship between budget quality and budget goal clarity.

Budget goal clarity is part of the impact of government accountability, which is related to the accountability of government administration and professionalism in managing local government budgets. In testing the hypothesis locus of control is not able to strengthen or weaken the relationship between external pressure and environmental uncertainty with the clarity of budget targets, because of the individual belief that the local government cannot control the events in life it faces (internal locus of control) in the form of environmental uncertainty at the time. the process of realizing the use of the budget or an individual's belief that the environment controls events in their life (external locus of control), so that the public is not sure of the local government on its vertical responsibility to the central government and horizontal accountability to the regional people's representative assembly (DPRD)

\section{CONCLUSION}

The conclusion of the research results, partially of external pressure, environmental uncertainty, budget quality, locus of control and value for money have a significant effect on budget goal clarity. The higher the external pressure, and the unclear environment, the less clear the target will be. Then the results of the moderation test show that value for money is able to weaken the relationship of external pressure, environmental uncertainty on budget goal clarity, the meaning implementation of value for many can increase of budget goal clarity, and weaken external pressure and reduce environmental uncertainty on budget goal clarity. Whereas locus of control, as a moderating variable, is able to improve the relationship between budget quality and the clarity of budget targets, meaning that local governments, which have a quality budget, will be able to increase clarity of budget targets in accordance with previous planning.

The recommendations of this research result for academic researchers to add variables to budget governance, regional political connections and increase research areas in Indonesia. Recommendations for local governments in achieving on budget goal clarity should be consider for implementation practices of value for money and budget quality in performance-based budgeting so that performance-based targeted budgets are achieved. The implementation of value for money through three value for money concepts, namely 
economical (saving carefully) in the procurement and allocation of resources, efficiency (efficient).

\section{REFERENCES}

Adisasmita, R. (2011). Regional Revenue and Budget Management. Yogyakarta, Graha Ilmu.

Adiwirya, M. F., \& Sudana, I. P. (2015). Akuntabilitas, Transparansi, dan Anggaran Berbasis Kinerja padaSatuan Kerja Perangkat Daerah Kota Denpasar. E-Jurnal Akuntansi Universitas Udayana, 11 (2), 611-628.

Amelia, R. (2015). The Influence of Internal Control, Accountability, External Pressure, and Commitment of Leaders on the Implementation of Financial Reporting Transparency. Online Journal of Students of the Faculty of Economics, University of Riau, 2(2), 1-15

Andrianto, N. (2007). Transparency and Public Accountability through e-Government. Malang: Banyumedia Publishing.

Andriyani, L. (2016). Influence of External Pressure, Management Commitment, Environmental Uncertainty, Leadership Style, and Accessibility of Financial Reports on the Implementation of Financial Reporting Transparency (Survey on the Regional Work Unit of the Pelalawan Regency Government). Management Organization Journal, 3(1).

Dwi, K. P., Hartono, A., \& Garuh, A. F. M. (2018). External Pressure, Environmental Uncertainty, and Management Commitment to the Implementation of Financial Reporting Transparency. Journal of Economics, Management and Accounting. 3(2).

Gede, E. A. K. (2014). The Influence of Clarity of Budget Objectives, Organizational Commitment and Environmental Uncertainty on Budget Accuracy (Empirical Study in SKPD of Bali Provincial Government). E-Journal of Economics and Business, Udayana University, 3(04).

Fernandes, W., Kennedy., \& Hanif, R. A. (2015). Pengaruh Akuntabilitas, Transparansi dan Pengawasan Terhadap Kinerja Anggaran Pada Pemerintah Daerah Kabupaten Kampar. JOM FEKON, 2(2), 1-13.

Hamdi, F., Hardi., \& Azhar, A. L. (2017). Pengaruh Akuntabilitas, Tekanan Eksternal, Komitmen Manajemen, dan Kompetensi Sumber Daya Manusia Terhadap Penerapan Transparansi Pelaporan Keuangan (Studi Pada Satuan Kerja Perangkat Daerah Kabupaten Indragiri Hulu). JOM FEKON, 4(1), 1-15

Hanafiah, R. R., S. Abdullah \& M. Saputra (2016). The Influence of Accountability, Transparency, Human Resource Capacity, and Internal Control on Regional Financial Management (Study at SKPD Pemerintah Kabupaten Aceh Utara). Journal of Accounting Administration: Unsyiah Postgraduate Program, 5(4), 77-86

Hidayat, T. (2016), The Effect of Clarity of Budget Objectives, Decentralization Structure and Locus of Control on Managerial Performance. Journal of Accountability, 8(2). 
Wati, Tjaraka, \&Sudaryati, Do Managerial Ability Impact...

Huseno, T. (2017). Pengaruh Partisipasi Anggaran, Komitmen Organisasi dan Ketidakpastian Lingkungan Terhadap Senjangan Anggaran Pemerintah Provinsi Sumatera Barat. Jurnal Teori dan Riset Administrasi Publik, 1(1).

Karacan, E., \& Yazici, K. (2015). Performance-Based Budget Arrangements, the Implementation Process and Advancements in Turkey. International Journal of Business and Social Science 6 (4): 62-79.

Mangkuprawira, Tb. S. (2014). Strategic Human Resource Management. Ed.2. Bogor: Publisher Ghalia Indonesia.

Mardiasmo. (2009). Public Sector Accounting. Yogyakarta: Andi Yogyakarta.

Masruroh, A. F. (2015). Factors Affecting the Transparency of City Government Financial Statements. Journal of Accounting Science and Research, 4(7), 1-20.

Nasrul, L. (2017). The Influence of External Pressure, Uncertainty, Environment and Management Commitment to Financial Reporting Transparency. Journal of Accounting Economics Research (JENSI), 1(1).

Nopriyanti, E., Azlina, N., \& Hasan, M. A. (2016). Pengaruh Partisipasi Anggaran, Penekanan Anggaran, Komitmen Organisasi, Locus of Control, dan Kompleksitas Tugas Terhadap Kesenjangan Anggaran (Studi Empiris Pada Skpd Kabupaten Agam). JOM FEKON, 3(1), 777-791.

Noprizal, R., Tanjung, A. R., \& Hariyani, E. (2017). Pengaruh Tekanan Eksternal, Ketidakpastian Lingkungan, Komitmen Manajemen Dan Sistem Pengendalian Pemerintah Terhadap Penerapan Transparansi Pelaporan Keuangan Pemerintah Daerah (Studi Empiris Pada Satuan Kerja Perangkat Daerah Kabupaten Indragiri Hulu). JOM FEKON, 4(1), 1066-1080.

Pello, E. V. (2014). Pengaruh Asimetri Informasi dan Locus of Control pada Hubungan Antara Penganggaran Partisipatif Dengan Senjangan Anggaran. E-Jurnal Akuntansi Universitas Udayana, 6(2), 287-305.

Premananda, N. L. P. U. \& M. Y. Latrini. (2017). The Effect of Accountability, Transparency, and Budget Participation on Budget Performance in Denpasar City Government. E-Journal of Accounting, 18(3), 2451-2476.

Pertiwi, D. P. (2015). The Effect of Accountability, Transparency, and Supervision on Budget Management with a Value for Money Concept in Government Agencies (Empirical Study of the Riau Province SKPD). JOM FEKON, 2 (2), 1-15.

Anugerah, R. P., Taufik, T., Haryani, E. (2015). Pengaruh Kejelasan Sasaran Anggaran Dan Ketidakpastian Lingkungan Terhadap Akuntabilitas Kinerja Instansi Pemerintah Daerah Dengan Kinerja Manajerial Sebagai Variabel Moderasi (Studi Empiris Pada Satuan Kerja Perangkat Daerah Kota Pekanbaru). JOM FEKON, 2(2), 1-15

Purnamasari, R. D. W., \& Handayani, N. (2015). Pengaruh Sumber Daya Manusia, Tekanan Eksternal, Komitmen Manajemen Terhadap Transparansi Pelaporan Keuangan. Jurnal Ilmu dan Riset Akuntansi, 4(2).

Ridha, M. A., \& Basuki, H. (2012). The Influence of External Pressure, Environmental Uncertainty, and Management Commitment on the Implementation of Financial Reporting Transparency. Accounting National Symposium XV Banjarmasin. 
Saputro, F., irianto, B. S., \& Herwiyanti, E. (2016). Faktor yang Mempengaruhi Ketepatan Anggaran Sektor Publik. Soedirman Accounting Review, 1 (2), 21-39.

Saskia, N. A., Amin, M., \& Junaidi. (2020). Pengaruh Kejelasan Sasaran Anggaran, Perwujudan Nilai Transparansi, Pengendalian Akuntansi, Akuntabilitas, Value For Money, Terhadap Pengelolaan Akuntansi Keuangan Sektor Publik. Jurnal Ilmiah Riset Akuntansi, 9(11), 53-69.

Setyowati, D. F. (2017). The Influence of External Pressure, Human Resources, Management Commitment, and Environmental Uncertainty on the Implementation of Financial Reporting Transparency. Repository Muhammadiyah University of Yogyakarta.

Silva, L.M.D., \&Jayamaha, A. (2012). Budgetary Process and Organizational Performance of Apparel Industry in Sri Lanka. Journal of Emerging Trends in Economics and Management Sciences (JETEMS), 3(4).

Suluh, A.R.B. (2014). Pengaruh Karakteristik Penganggaran Terhadap Kinerja Pelaksanaan Anggaran Pemerintah (Studi Pada Satuan Kerja Lingkup Wilayah Kerja KPPN Malang). Jurnal Ilmiah Mahasiswa FEB, 1(2).

Suryandari, E. F., \& Mukti, G. B (2019). Pengaruh Ketidakpastian Lingkungan, Akuntabilitas, Tekanan Eksternal, Pengendalian Internal, Dan Komitmen Manajemen Terhadap Penerapan Transparansi Pelaporan Keuangan (Studi Empiris Organisasi Perangkat Daerah Kabupaten dan Kota di Daerah Istimewa Yogyakarta). Jurnal Sosial Ekonomi dan Humaniora, 5(2), 140-150.

Triana, M., Yuliusman., \& Putra, W. E. (2012). The Effect of Budget Participation, Budget Emphasis, and Locus of Control on Slackbudget (Survey on Star Hotels in Jambi City). E-Jurnal Binar Akuntansi, 1(1).

Wandari, I. D. N. T., Sudjana, E., \& Adi, M. P. (2015). The Effect of Accountability, Transparency, Timeliness and Internal Control on Budget Performance with a Value for Money Concept at Government Agencies in Buleleng Regency. JIMAT 3(1), 1-12.

Wimba Wardhana, A. A. G., \& Gayatri, G. (2018). Pengaruh Partisipasi Anggaran, Asimetri Informasi, Ketidakpastian Lingkungan, Budaya Organisasi, dan Komitmen Organisasi pada Senjangan Anggaran. E-Jurnal Akuntansi. doi:10.24843/eja.2018.v25.i03.p18

Yunaz, A. R. (2016). The Influence of External Pressure, Environmental Uncertainty, Organizational Commitment, and Level of Financial Report Disclosure on the Implementation of Financial Report Transparency. Riau University Student Online Journal, 3(1). 